\title{
The Sierra Leone Conflict: The Plight of Refugees and the Displaced
}

\author{
Veronica Nmoma
}

\begin{abstract}
As a result of the Liberian civil war, Sierra Leone became simultaneously a major generator and receiver of refugees. Charles Taylor and his National Patriotic front of Liberia, along with Sierra Leone's Foday Sankoh's Revolutionary United Front (RUF) incursion into Sierra Leone in March 1991, had a profound impact resulting in at least 10,000 casualties, about a million internally displaced peoples and some 300,000 refugees in neighbouring states. This paper argues that the RUF objective was unclear all along, as it lacked ideology and that, even now, it has yet to put forward a coherent program.
\end{abstract}

\section{Précis}

La Sierra Leone est devenue à la fois nation productrice et nation-hôte de réfugié(e)s d̀ cause de la guerre civile au Liberia, un pays voisin. Charles Taylor et son front patriotique national du Liberia, et la poussée dans son pays natal du léonais Foday Sankoh et son front révolutionnaire uni (RUF) en mars 1991, ont provoqué au moins 10000 morts, le déplacement interne d'un million de personnes et environ 300000 réfugié(e)s dans les contrées voisines. L'auteure soutient que l'objectif du RUF a toujours manqué de précision, de fondement idéologique et que, a l'heure actuelle, il n'a toujours pas présenté de programme cohérent.

\section{Introduction}

Of all Liberia's neighbours in West Africa, the one most affected by the Liberian civil war has been Sierra Leone. As the Liberian conflict spread

Veronica Nmoma is Assistant Professor, Department of African-American and African Studies, University of North Carolina at Charlotte, USA. into Sierra Leone (a small West African country about the size of New York), both countries at once, and for the first time, were subject to the displacement of their peoples and mass refugee movements. In Sierra Leone, Corporal Foday Sankoh's Revolutionary United Front (RUF) mounted an insurrection against the APC administration of then President Joseph Momoh (1986-1992). Following a coup in 1992, the RUF offensive continued against the military government of Captain Valentine Strasser (1992-Jan 1996).

Ostensibly, RUF's objective was to end the corrupt and dictatorial government of Momoh because it failed to comply with public demands for multi-party elections. However, when the Strasser government called for the cessation of hostilities with the promise of elections for 1996, RUF failed to comply. Sankoh and his rebels continued to lay waste to villages and attack diamond and bauxite mines, while, at the same time, a heavy assault was launched on the innocent civilians whose interests RUF claims to represent.

This paper chronicles the impact of Sierra Leone's political instability on its population, much of which has been forced to seek asylum in neighbouring states. The paper argues that the interests of the people of Sierra Leone were never at the heart of the RUF rebellion. Rather, it appears that the rebels were solely driven by greed and lust for power.

\section{Background to Rebel Incursion: Liberian Refugee Influx into Sierra Leone-1990}

Sierra Leone has been largely dysfunctional as a result of the rapid influx of refugees precipitated by the war in $\mathrm{Li}$ beria. This refugee movement began in May 1990 with the approach of Taylor's NPFL forces to the outskirts of
Monrovia. Approximately 1000 people, mainly Krahn and Mandingo groups from Monrovia and western Liberia crossed daily into Sierra Leone. In mid-June, more than 20,000 refugees had settled in Sierra Leone. By August of 1990 , this number had risen to some 69,000 . In September, the number had spiralled to 86,000 , and by October, the number of Liberian refugees in Sierra Leone slightly rose to some 130,000 . Still, Sierra Leone had relatively fewer Liberian refugees when contrasted with Guinea's 400,000 or Côte d'Ivoire's 300,000.

Many refugees arrived by bus loads and private cars, but the majority entered by ship. They had no difficulties gaining entry into Sierra Leone. As citizens of a member country of the Economic Community of West African States (ECOWAS) and the Mano River Union (MRU), ${ }^{1}$ the Liberian refugees were not required to have visas of entry and enjoyed the benefits of freedom of movement and the right of settlement in Sierra Leone. However, following the 1992 military coup, and in light of continued rebel attacks and atrocities, the Sierra Leonean government demanded that new incoming refugees be registered on entry.

As the number of the refugees greatly increased, accommodating them presented major problems. Some of them were housed in crowded camps and settlements, while another 500 slept in Sierra Leone's national stadium. In addition, the refugees were also faced with limited access to clean - water and sanitation. In most cases, the enormous responsibility of feeding and caring for the refugees fell to local families. This was particularly burdensome as many of these families were, themselves, poor and lacked the resources to support their own families.

Although the government and people of Sierra Leone were hospitable 
and generously shared their meagre resources, the political and economic impact of this massive inflow of Liberian refugees was devastating and should not be underestimated especially in the light of Sierra Leone's situation as one of the poorest African countries. At the time, Sierra Leone was already experiencing economic crisis due to its weak economy. The Liberian refugees constituted, therefore, an enormous burden on the host government and the local community networks.

The refugee influx placed a heavy demand on the country's natural resources as well. Heavier demands for fuel and timber from the forest, triggered an increase in firewood prices. The presence of refugees also increased the need to hunt for wildlife and placed a heavy burden on basic social services and related infrastructures. Rent and the prices of basic commodities jumped further straining social services, and unfortunately, the initial influx of refugees coincided with the country's hunger season (a few months before the rice harvest season). The additional hardship created by the refugees' presence was overbearing as then President Momoh explained: "We are overstretching our resources to take care of his people [Liberia's Taylor], our social amenities are being over-taxed and even our economy has been dislodged." 2 The influx of refugees took its toll on Sierra Leone's economy which had serious political repercussions for the government.

\section{The Sierra Leone Incursion, the Displaced, and the Refugees in 1991}

In March of 1991, the Liberian civil conflict, itself, spilled into Sierra Leone. Taylor's NPFL invaded Sierra Leone's southern province, in retaliation for Sierra Leone's participation in ECOMOG and the use of Freetown Lungi Airport as a base for air strikes on NPFL positions and military facilities. ${ }^{3}$ At first, the NPFL leader threatened retaliation in an attempt to force Sierra Leone to withdraw from
ECOMOG. Accordingly, the NPFL, joined forces with Sierra Leones' former Corporal Foday Sabanoh Sankoh and his RUF insurgents, and made several incursions into Sierra Leone. These resulted in the deaths of many Sierra Leoneans, as well as the displacement of hundreds of thousands of persons. ${ }^{4}$ In addition, some 160,000 persons were forced to flee to Guinea and about 12,000 desperate persons fled to war-torn Liberia to escape the violence and attacks on civilians.

The Momoh administration then deployed 2,150 government soldiers along the Liberian border. In retaliation against Taylor's aggression, Momoh supported the Sierra Leone based United Liberation Movement for Democracy (ULIMO). ULIMO, one of the factions in the Liberian civil war, launched an offensive against Taylor's territory in Liberia, scoring major victories. The NPFL faction's incursion into Sierra Leone in March 1991 illustrates the extent and capacity of rebel forces to threaten and destabilize the security of the West African region and the international community as a whole. Taylor's guerrilla insurrection was no longer a strictly Liberian affair. The invasion of Sierra Leone raised concerns in the West African states that the presence of Liberian refugees could pose a security risk for the entire region.

At first, Taylor denied any involvement in that Sierra Leone's guerrilla insurgency, but, later, a statement by his foreign minister, Ernest Eastman, confirmed the involvement. Eastman said that Taylor regretted that "some of our boys went into the Sierra Leone section and perhaps over-indulged." 5 Thereafter, some eighty-three NPFL soldiers were captured by Sierra Leone's military commander, Major-General Shieku Tarawali, thus confirming the suspicions of NPFL involvement. RUF was an ally of Taylor and was supplied with weapons, personnel, and financial support from Taylor. ${ }^{6}$ Following the initial incursion, Sankoh did claim responsibility, when he announced that RUF intended to overthrow the Momoh government because of its failure to concede to demands by the Sierra Leneans for multiparty elections. However, comparable to the Liberian case, the Momoh government was toppled in 1992, but the RUF guerrilla war has raged on. "That is the strange thing about this war," says J. O. D. Cole, Secretary General of the Sierra Leone Bar Association. "We have no idea who they are, what they're fighting for, and we don't even know who their leader is."

The rebels professed to be waging a war against the government, claiming throughout that their goal was to protect the civilian population. Yet, the pattern of their atrocities has been very similar to that of the NPFL and some other rebel groups in Liberia. As soon as the rebels crossed into eastern Sierra Leone, they captured villages and towns, looted homes, and intimidated, terrorized, and dislocated local populations. Renegade members of the NPFL are alleged to have killed many civilians while looting homes, stealing property, and raiding the border towns of Potoru and $\mathrm{Zimmi}^{8}$ As the rebels attacked the towns of $\mathrm{Njala}$ and Njaiama, for example, they pounded civilians, burning some ninety-six persons to death. Convoys carrying civilians were particularly targeted, but ironically, military convoys were not attacked. Indeed, the guerrilla war traumatized the countryside, spread fear in the country, and prompted a population flight into neighbouring Guinea and Liberia.

Following the clashes with the rebels, the Sierra Leone security forces harassed and intimidated Liberian refugees in Sierra Leone. ${ }^{9}$ Thus, these refugees also became victims of the border clashes between the NPFL and the Sierra Leonean national army. Worsening the situation, the Taylor faction's incursion into Sierra Leone not only displaced some 145,000 Sierra Leoneans but also caused some Liberian refugees in that country to flee again, forcing some to return to Liberia. The crisis also disrupted the relief program for some 125,000 Liberian refugees in Sierra Leone. Unfortu- 
nately, the refugees who fled to Liberia were unable to receive emergency relief until the middle of 1992, as they were cut off from relief organizations following the August 1991 Ulimo rebel incursion from Sierra Leone into Liberia. Non-governmental organizations (NGOs), working in conjunction with the UNHCR, facilitated a voluntary repatriation to Monrovia of some Liberian refugees uprooted by the March assault on Sierra Leone.

Among the Sierra Leonean refugees who fled into Guinea, some went deep into the more remote areas, which were often less accessible. They settled in the Gueckedou area creating overcrowding and often outnumbering the host population. Those who settled in this area did not receive any food allotment for the first two months following their arrival. ${ }^{10}$ On the other hand, the refugees that fled to other areas in Guinea were somehow fortunate in that a relief system was already in place. When the Sierra Leonean refugees arrived, the aid program was simply expanded.

Momoh's incompetent government was unable to control the rebel incursions and their deadly activities in southeastern Sierra Leone. It, therefore, sought military assistance from member states of ECOWAS. In response, Nigeria and Guinea sent troops to assist the government forces. Those foreign troops were deployed to safeguard key strategic areas, and with the aid of Nigerian and Guinean military forces, the government army secured the southeastern territory, deterred RUF attacks and regained captured areas in the southern and eastern sections. One of the places recaptured from the rebels was the town of Pejehun. An observer recounts her horrendous experience: ${ }^{11}$

The rebels arrived on Saturday, April $20, I^{\prime} \mathrm{d}$ heard rumors about the rebels, but hadn't thought they'd attack this town. When they did, I was engulfed in fear. A rebel entered my house ... he told my husband to go outside, then shot and killed him. I saw him being shot. I saw his blood running. They didn't allow me to bury him until the following Thursday. His body remained on the spot ... Most people fled the town. Very few remained. I heard everywhere else had also been attacked, so I decided to stay. Every day they killed people. Before they killed them, they tied their hands behind their backs and paraded them around the town naked-men and women. They'd slice their ears off, put them in their mouths, and make them chew them.

Despite ECOWAS support, the rebel insurgency was difficult to contain because RUF employed guerrilla tactics such as hit and run attacks. In the face of the guerrilla warfare, air strikes by the military were largely ineffective, although the government seemed to have had an upper hand in that, at first, it appeared to have repelled the invasion. But the insurgency did not end as rebel guerrilla fighters, employing terror tactics, targeted schools, government buildings and facilities, institutions, government workers and health clinics. Government loyalists were ambushed and killed while recaptured towns were raided creating chaos and more displacements. After spreading more confusion, the guerillas would disappear into the bush only to return at a later date.

Some of the displaced fled to the cities where they stayed in homes of friends and relatives. Due to the fighting and poor road conditions, relief workers were unable to reach out to the needy and starving refugees among whom the Médecins Sans Frontières found a malnutrition rate of 43 percent among some 15,000 refugees.

By the end of 1991, the crisis had killed at least 10,000 persons and idisplaced roughly a million people. The fighting between the RUF guerrillas and the government's army in the southeastern region caused the idisplacement of roughly 290,000 persons. Some 140,000 people fled to Guinea and 115,000 went to Liberia. Among those that fled to Liberia were some who had arrived in Sierra Leone in 1990. This effectively began to reverse the trend as the number of Liberians in asylum in Sierra Leone fell drastically to 50,000 in July 1991 from 125,000 in March of that year.

The decline in the number of refugees in Sierra Leone continued as the rebels intensified their offensive against the ill-trained government soldiers. By October 1991, the number of refugees remaining in Sierra Leone had dropped to some 20,000 , and decreased by one half, to 10,000 , by December of $1991 .^{12}$ Of the $10,000 \mathrm{Libe}-$ rian refugees left in Sierra Leone, 5,000 were still settled at the Waterloo Camp near Freetown; 3,000 were scattered mainly in eastern Sierra Leone; and 2,000 were gainfully employed in the Sierra Leonean economy.

\section{The Worsening Situation in 1992}

In the midst of the civil crisis, the Sierra Leonean case became more complicated as the country not only had to cope with hosting refugees from Liberia and repelling a guerrilla insurgency, but also experienced a military coup (not at the hands of the insurgents) staged by junior army officers. Following the coup, the newly-established National Provisional Ruling Council (NPRC) nominated 27-yearold Captain Valentine Strasser as Chairman and Head of State. ${ }^{13}$ Strasser, a leader of the coup, was also a veteran of the war who had fought with the national army trying to repel the rebels in the southeastern region. Following his overthrow, President Momoh fled to Guinea joining other Sierra Leonean refugees in that country.

However, as in Liberia, the overthrow of the Momoh government did not mean an end to the Sierra Leonean civil crisis. On assuming the country's leadership, Strasser's military government vowed to bring an immediate end to the rebel incursion. Through diplomatic channels, the NPRC approached RUF rebels offering a ceasefire, unconditional talks, amnesty, and a negotiated settlement. The government and RUF were unable to reach an agreement, so that violence raged on and more civilians were forced to flee into neighbouring Guinea, Liberia, 
and deeper into Sierra Leone, further away from the border.

Sierra Leone was affected again as Taylor's NPFL launched a surprise attack on Monrovia on October 15, 1992. Once again the attack displaced many Sierra Leonean refugees in Monrovia forcing the UNHCR to organize a voluntary repatriation program for them. As a result, some 5,000 refugees were voluntarily repatriated from Liberia by ship, and another 13,000 returned to their homes by land. This was in spite of worsening conditions in Sierra Leone. Similarly, during the same year, 1,600 Sierra Leonean refugees in Guinea returned home voluntarily with UNHCR assistance.

By December 1992, approximately 20 to 25 percent of Sierra Leone's 4.5 million people were displaced as a result of fighting between RUF guerrillas and government soldiers. As the Sierra Leonean government forces made progress into rebel-held territories, many internally displaced persons, trapped in these areas, received no support, and therefore, returned to government-controlled areas. Some Liberian refugees, previously accommodated in private homes as they fled from the new rebel onslaught, arrived to join others at the Waterloo Camp near Freetown. Yet, some 8,000 others remained scattered in the country, mainly in Kanema, Freetown and Bo. In addition, at year's end, some 260,000 Sierra Leoneans had sought asylum in the surrounding nations. While approximately 400,000 of the displaced were in camps, other displacees, nearly 400,000 , did not reside in camps. As expected, those displaced people who sought refuge in the country lived in endless fear and experienced distress and severe hardships as they faced unexpected attacks.

\section{Intensification of the War and Its Impact in 1993-94}

Reports of human rights abuses underscored the increasing violence and atrocities committed by dissident government soldiers. These included robbery, extortion, looting, and the killing of innocent civilians. ${ }^{14}$ The violence also claimed the lives of missionaries and relief workers. Due to the security threat in southeastern Sierra Leone, relief operations were considerably impeded and, in some areas, they were actually suspended. For instance, the International Committee of the Red Cross (ICRC) suspended its operation following an attack on its convoy in August 1993 in which two ICRC nurses were killed. ${ }^{15}$ Also, at year's end, the number of Sierra Leonean refugees in Guinea and Liberia were estimated at 260,000 and the displaced at about half a million. ${ }^{16}$

Fighting intensified in 1994, spreading into the northern and central regions of the country, areas previously unaffected by the war. The civilian population, moreover, suffered from harassment, assault, torture, rape and other atrocities. Even though the country was still subject to RUF rebel attacks in 1994, many people in Sierra Leone believed that most of the human rights infractions, ambushes, looting, and raiding were caused by disgruntled government soldiers. As some displacees explained, "these former or current soldiers had discovered that they could ambush convoys, loot towns, kill and maim civilians, and control localized portions of the diamond trade with near total impunity." 17 In addition, officials of the United States' Committee for Refugees conducted a site visit in Sierra Leone toward the latter part of 1994 and reported that uncontrolled and vicious elements in the government army posed the "greatest threat to security, liberty, property, and human rights in Sierra Leone."18 Under the circumstances, many unarmed and innocent civilians were killed not only by the RUF's undisciplined, untrained, and impoverished recruits, independent bands of bandits, but also by dissatisfied current and former government soldiers.

In April 1994, for example, about thirty persons, including children, were seized from the bush where they were taking refuge in the villages of Dodo and Kotuma. Suspected of collaborating with dissident troops, they were brought to the town of Buedu where twenty-five of them were killed by government forces ${ }^{19}$ while attacks around Bo and Kanema left many civilians dead or starving when they were cut off from relief assistance. Several persons drowned in the Sewa river as they attempted to flee the rebel attacks. Akin to Liberia, displaced people's camps were constantly terrorized by rebels precipitating multiple displacements. Even Sierra Leone's largest refugee camp in Gondoma, south of Bo, was not spared. Several persons were killed when rebels overran the settlement of 80,000 internally displaced persons on Christmas eve.

While these atrocities were being perpetrated, armed gun men hidden in bushes threatened and prevented emergency relief supplies from reaching the starving population. The rebels specifically targeted major roads, as was the case of the roads joining Bo and Kanema and also those connecting Koida and Makeni. Here one could travel only under military escort. Convoys were constantly attacked resulting in the death of many civilians and troops.

Often with the intention of looting, armed men would employ a variety of means to create rumour, confusion and fear and scare off whole villages. Once the inhabitants would flee, the men would loot and destroy homes. For example, they might fire a shot near a village they intended to plunder, or cut off a messenger's arms as a sign of their impending arrival. In one such incident, a truck driver had gone to purchase rice for the villagers and was seized by armed men. The driver recounted that "rebels cut off my hands and told me to go to Panguma to tell the soldiers that they were going to attack." 20 In another instance, when more than 20,000 residents of Gerihun fled towards Bo, many drowned in the river in desperate attempts to escape the armed gangs.

In 1994, therefore, over one million persons, that is, at least one-fourth of Sierra Leone's population was displaced, and many people were dis- 
placed three or more times. Reports estimated that roughly 300 persons were killed each month in 1994 due to the fighting and bandit attacks. Many others died from starvation and disease. A nurse in charge of a hospital in Kanema, once a prosperous city, said poignantly:

Since December all we have known is death-by killing, by famine, or by cholera .... The rebels would attack one side of the city, and the entire population would flee to the other. For the villagers, everything has been destroyed. Nothing was left untouched. ${ }^{21}$

Thus, one refugee equally lamented:

\begin{abstract}
Life in Bo is very difficult. Three months ago, there were eight of us in the family. Two of our daughters died of starvation a month ago and my brother died of cholera two weeks ago." 22
\end{abstract}

Throughout 1994, the number of the displaced people was constantly increasing, as hundreds of thousands of people were uprooted several times as a result of rebel attacks. For security reasons, many of the relief organizations were unable to reach starving persons, particularly, in the eastern and northern parts of the country where the fighting continued. Similarly, many Liberian refugees in Sierra Leone had to flee again when their refuges suffered massive rebel assaults.

Equally alarming were the number of persons who remained as refugees in the neighbouring countries. In December, that number was estimated at 260,000 as noted above. Guinea had 160,000 refugees, and Liberia accommodated 100,000. In spite of the ongoing war and the degenerating conditions, over 30,000 Sierra Leonean refugees in Liberia and Guinea returned home. However, shortly thereafter, they were again uprooted as rebels accelerated their attacks. Gondoma and Gerihun camps housed some 60,000 and 20,000 displacees by the year's end, and some 20,000 Liberian refugees remained in Sierra Leone.

\section{The 1995 Attempts at Negotiations}

Attempts by the military government to negotiate an end to the turmoil were unsuccessful until 1995. A three-daynational conference was held in Freetown around mid-August 1995. An invitation was extended to the RUF rebels to attend, but the rebels did not take part in the talks. As they gained strength, the rebels refused to negotiate an end to the crisis in the belief that the government was in a weak and vulnerable position.

The situation became ever more complex for the government, as some of its own soldiers began assisting the rebels. Some of these soldiers were known to fight as part of the government force during the day, and at night, to team up with the rebels. ${ }^{23}$ These "traitors" have been described and nicknamed by some Sierra Leoneans as "Sobels."

Towards the latter part of 1995, the rebels intensified their bloody campaign against civilians and military targets throughout the rural area. They frequently ambushed key roads linking two towns. This was the case when the road connecting Kono and Freetown was attacked, and the rebel activities hampered relief operations. Their tactics aimed at civilians were no different from those of the Liberian rebels. As in Liberia, Sierra Leone insurgents killed tens of thousands of civilians and destroyed whole villages. Many villagers, having nothing to eat, fed on wild roots and consequently died of starvation, malnutrition and disease. A 28-year-old mother of four, who lost two çhildren due to malnutrition, agonized as she recounted her experience: "We lived on nothing but rice for one year, then my village was destroyed one night by the rebels. We were fortunate enough to escape, but everywhere we went there was no one to help us and nothing to eat." 24 Equally, over 150 displaced persons that escaped from the war-torn areas into the Mambolo Chiefdom in Kambia District were neglected by the government and humanitarian relief agencies. They were desperately in need of food, clothing and health care services. ${ }^{25}$

However, in spite of the participation of mercenaries and troops from other countries in the region, the war has largely been one of capture (of a district, town, or a mineral strategic area) by the rebel forces and recapture by the national army. Take, for instance, the Kono mineral district: it has been captured three times by the RUF rebels. Unfortunately, within these recurring onslaughts, thousands of civilians have been killed; nearly a million people have been displaced, and hundreds of thousands of people have become refugees in neighbouring states.

\section{The 1996 Elections and the \\ Expected Return of the Displaced and the Refugees}

At the beginning of 1996, Strasser was replaced in a bloodless coup by Chairman Julius Maada Bio. Since the palace coup, the new military head of state has engaged in talks with the RUF, meeting for the first time in Côte D'Ivoire where both the government and rebels concluded a cease-fire agreement. In spite of attempts to disrupt voting by rebel and military factions, ${ }^{26}$ Sierra Leone successfully carried out a peaceful democratic national election in March with the President elect, Ahmad Tejan Kabbah, sworn into office in April. The new government committed to real dialogue, met almost immediately with rebel leader Sankoh in Côte D'Ivoire and was able to consolidate a temporary peace accord so that the Sierra Leonean refugees would return home. Although the war-torn nation appears to be on its way to peace, a final agreement for a political solution has yet to be signed.

\section{Conclusion}

The people of Sierra Leone have indeed been traumatized by the senseless rebel war. As one observer lamented:

$\ldots$ there is terror in every corner of this country today as the rebels keep mounting offensives against innocent civilians. The old men are in hid- 
ing - that is those that have survived the guns and machetes of the rebels and the sobels-the old women are languishing in displaced camps, the young men and women have become fighters-either on Sankoh's side or on the government side, and our children have become aimless orphans with a dark future. ${ }^{27}$

However, until a lasting peace is attained, the rebel war will linger and the plight of the displaced and the refugees will most likely worsen. The new government has called on the refugees to return, but there are no adequate plans for the repatriation and resettlement of refugees. Since the war has largely strained the meagre resources of the diamond-rich country, Sierra Leone is still classified among the poorest African nations and this impedes the return of refugees and the displaced.

It is hoped that the new democratic government will succeed in ending the five-year-old war. As one observer noted, "a new diplomatic approach initiated by new players may very well encourage the accommodation necessary to bring an end to the war, which the NPRC has been unable to do." 28 With the recent multi-party elections (a motive for the war), Sankoh might finally disarm his rebels and engage in genuine dialogue committed to working out differences amicably. It is now up to the rebels, the government, and its citizens, to arrest the processes that have continued to precipitate cyclic instability and retarded development. Hopefully, a new Sierra Leone will one day emerge and become the "model African nation" its founding fathers and mothers envisioned.

\section{Notes}

1. Sierra Leone, Liberia and Guinea are members of the Mano River Union (MRU) formed in 1973. One of the main objectives is that of the MRU's collective security of member nations. Besides, $\mathrm{Si}$ erra Leone has security treaties with both Liberia and Guinea.

2. "Momoh Lashes at Taylor," West Africa, 19-25 November 1990, 2875.

3. Relations between Sierra Leone and Liberia was strained for nearly one year (No- vember 1985-August 1986), when former Liberian President Doe accused Momoh of involvement in a coup to topple his government. However, relations were normalized in August 1986 following the signing of a nonaggression treaty and security cooperation between the governments of Liberia, Sierra Leone and Guinea.

4. Sankoh is an acquaintance of Taylor. Both received military training in Libya in 1989. Sankoh participated in the December 24, 1989 Liberian invasion before moving home in 1991 with his RUF. Taylor worked in cooperation with dissident Sierra Leoneans. It is not clear what the RUF rebels want. No one is absolutely sure if Sankoh is still leaving or dead. In an interview, an observer explained that "Sankoh exists as a mask, the African mask that we put on."

5. "Liberia," Africa Report, May-June 1991,7.

6. "War For The Sake Of War," U.S. News and World Report, 17 July 1995, 35-36.

7. Ibid., 37.

8. "Liberia," Africa Report, 7.

9. "Conflict in Liberia: Nine More Months," Africa News, July 21, 1991,9.

10. Ruiz, "Uprooted Liberians: Casualties of A Brutal War," Issue Paper, Washington D.C.: United States Committee on Refugees or USCR 1992, 21-22.

11. Ibid., 22.

12. "Sierra Leone," World Refugee Report, Washington D.C.: Department of State, 1992, 44.

13. Momoh's overthrow did not threaten $\mathrm{Si}$ erra Leone's membership in continued participation in ECOWAS peacekeeping efforts in the war-torn Liberia. Sierra Leone had contributed some 500 to 600 troops to the ECOMOG force.
14. Reports on Human Rights Practices, Washington, D.C.: U.S. Department of State, 1993.

15. Tom Argent, "The Usual People," Issue Paper, Washington D.C.: U.S. Committee for Refugees, 1993.

16. World Refugee Survey 1994, Washington D.C.: U.S. Committee for Refugees, 1994 65.

17. World Refugee Survey 1995, Washington D.C.: U.S. Committee for Refugees, 1995, 73.

18. Ibid., 74.

19. "Sierra Leone," Amnesty International Report, 1995, 259

20. Argent, "The Usual People," Issue Brief, February 1995.

21. Howard French, "For Sierra Leone, Elections and Starvation Loom," New York Times, 26 September 1995.

22. "Sierra Leone Civil War Is Causing Starvation," New York Times, 31 August 1995, A6L.

23. "Sierra Leone's War Targets Civilians, Industry, Foreigners," Africa Report, March-April 1995, 5.

24. Howard French, "For Sierra Leone, Elections and Starvation Loom," New York Times, 26 September 1995, A3L.

25. "Appeal for Aid to Displaced Nationals in Mambolo," Concord Times, 20 December 1995; 2 .

26. Howard French, "West African Peace Takes Root in Sierra Leone," New York Times, 5 May 1996, 1 and 12.

27. Sheka Tarawalle, "Christmas or CriesMass?" Concord Times, 20 December 1995, 4.

28. Garvas Betts, "The Road to Democracy," For di People, 9 January 1996, 6.

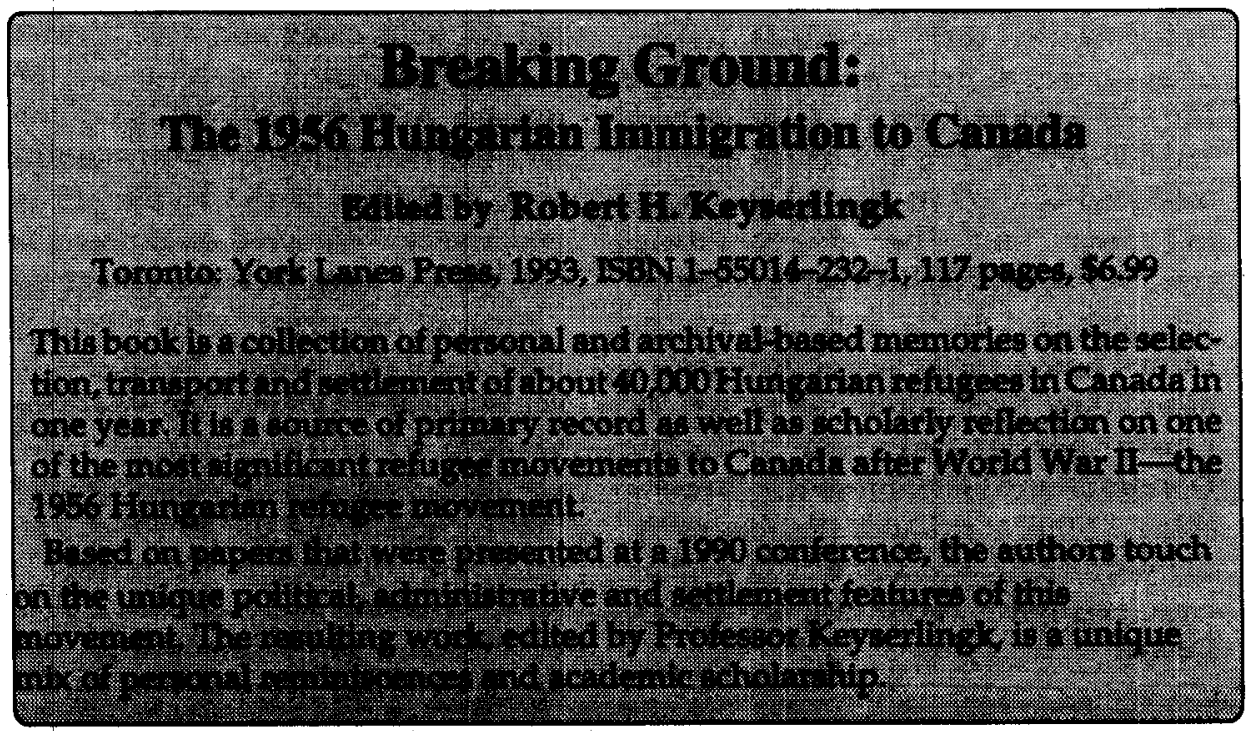

